\title{
The phenomenon of the Celebrity Preachers and the Awakening of the Religious Spirit of Millennial Generation in Indonesia
}

\author{
A S Rustan ${ }^{1}$, S J Amin ${ }^{2}$, M Haramain ${ }^{3}$, Nurhakki ${ }^{4}$ \\ IAIN Parepare, Jl. Amal BaktiNo.8 Soreang, Parepare, Indonesia ${ }^{1,2,3,4}$ \\ \{ahmadsultrarustan@iainpare.ac.id ${ }^{1}$, stjamilahamin@iainpare.ac.id $^{2}$, haramain@iainpare.ac.id ${ }^{3}$, \\ nurhakki@iainpare.ac.id $\left.{ }^{4}\right\}$
}

\begin{abstract}
This article aimed to examine the phenomenon of celebrity preachers and the religious revival of the urban millennial generation. Nowadays, celebrity preacher is a phenomenon that crowds the public space in Indonesia, especially in the information and technology media. The appearance of young, handsome, and classy preachers has influenced the world of da'wah among millennial youth in this country. Either aware or not, the awakening of this religious celebrity has changed the way of the young millennial generation in seeing life, especially the religious life of the motherland. These celebrity preachers are television and social media products, automatic religious messages delivered also follow the tastes of the media and often ignore the needs of da'wah subjects. This is also exacerbated by the condition, that not all celebrity preachers have an in-depth religious understanding. However, it can not be ignored, that these preachers have broken the tradition of 'preaching' which has been carried out by the chaplain. Communication skills, jokes, flashy appearance, and the ability to solve the problems of the daily life of the millennial generation are among the abilities possessed by these preachers. This is directly proportional to the current situation of the young millennial generation who no longer deals with and cares about the complexity of religious teachings, the depth of religious understanding, and the complexity of the systematic religious study. It seems that the current millennial generation prefers instantaneous, instant religious information, rather than systematic learning through formal educational institutions, such as pesantren and other religious schools. On one hand, this phenomenon is a positive trend. But on the other hand, it needs to be a concern of all parties, that in the future it is necessary to prepare young preachers who truly understand religion profoundly so that it does not seem just a mere spectacle and ignores the guidance. This phenomenon of celebrity preachers is reminiscent of the relevance and significance of "preachers certification" which some time ago was echoed by the ministry of religion. Of course, this becomes important to keep this religion truly well understood and profoundly.
\end{abstract}

Keywords: Celebrity Prechers, Millennial Young Generation, Da'wah, Social Medi, Television Media

\section{Introduction}

In the era of the 1980s until the 1990s, the da'wah sphere of our motherland was once phenomenal with the emergence of the 'king' of da'wah, K.H Zainuddin MZ. This million 
people preacher always deliver his da'wah material in casual language, so it is easy to understand. K.H Zainuddin MZ also tried to convey a touching message yet not offend anyone. Zainuddin's figure can be said to be a rare preacher who was ever born. His lectures are always soothing with a few jokes interspersed. One thing that is always remembered is the word 'betul' which is always said when asking a congregation. It was so enjoyable, that even when it rained and the sun stung the pilgrims did not want to move from their seats. This "Da'iSejutaUmat" used technology media in the form of radio and cassettes in delivering his da'wah.

This fact shows that no matter how great a preacher is, if he does not use information technology media, then the sphere of his preaching will not reach the whole society. In this era, it is the peak where everything is enjoyed instantly and a lot of preachers could preach or deliver preaching through existing media such as preaching with television, radio, and also written media[1]. The reality that there are so many preachers who have benefited from it, especially in television. Sometimes it turns out that it is not just the celebrities who want to be broadcasted on television, even the preachers also want to, until it is spread like mushroom everywhere[2].

This phenomenon shows, that the emergence of young preachers with a classy appearance, handsome, full of jokes is very popular among the people, especially among the millennial youth in the city. The preachers in many ways meet the desires of the entertainment industry: young, handsome, fashionable, good voice, and nice rhetoric. This provision also helped to facilitate them coming into the entertainment industry[3]. As part of the entertainment industry such as television, the preachers have become new celebrities with a commodity called Da'wah. They are famous, adored, and treated specially. Therefore, businesses do not hesitate to exhibit preachers as the image of their products. Especially lately some of them are able to become a trendsetter on products that make them their mascot.

The emergence of these young preachers coincided with the condition of the instantaneous millennial generation. A generation that no longer cares about the subtleties of religious teachings, the laziness of studying religion systematically. The point is, if there is a preacher who can answer the needs of the millennial era, then the preacher will be increasingly in demand. The depth of religious knowledge, like the kyai in the pesantren, is no longer a major prerequisite for becoming preachers and in demand by the younger generation[4]. This condition is showing a shift in religious orientation among the younger generation. This is also exacerbated by the media industry with special packaging to enable the appearance of preachers who prioritize entertainment and spectacle, not guidance.

This shift reducing the function of da'wah[5], [6]. The course was stuck on the packaging, no longer on the contents. The highlight is precisely the element of the spectacle. The guideline is only an inter-time feeder. The ability to entertain is used as the main measure of success in preaching. Da'wah no longer means how to show the public the path that is in accordance with the da'wah material, but merely means how to fulfill the producer's desire to get a high rating.[7] Preaching seems to be only an ability to convey verbal piety that should be commodified, without the label of the divine trust behind it. In fact, it is this mandate that actually demands that they practice the material of their da'wah in actional godliness as a form of social responsibility.

Although the emergence of celebrity preachers degrades the religious role of pesantren with all the depth of religious knowledge, on the other hand, the role of celebrity preachers also contributes positively to religious arousal among millennials. Previously, the millennial young generation, especially in urban areas, tended to be more luxurious in their lifestyle and ignored religious aspects, but now there is a revival of religious passion among this generation 
on a massive scale. At present, millennials have a high concern for the 'religion', hijrah and teachings held by the preachers. The young generation of Muslims in urban areas is facilitated by access to religious studies through social media, YouTube, and so on. Unfortunately, this concern for religion does not coincide with the systematization and the depth of religious understanding among the younger generation.

\section{Method}

The study is qualitative research that tries to construct an analysis related to da'wah and celebrity preachers in contemporary Indonesia. The data collection process is through several data sources that can be obtained by observation, and documentation. This study utilizes data in the form of a collection of texts, images, and videos that contain statements on social media, which specifically contains the discourse of celebrity preachers.

Furthermore, in the analysis of data, it will be elaborated related to text or posts in the form of videos and images from these cases. Not only the text, images, or video as a device of communicating messages, but the meaning contained in the use of language and text will be explained first by the author.

\section{Result and Discussion}

Several related sources said that Da'wah was meaningful, summoning, calling, pleading, inviting, encouraging. In a sense, preaching is intended as an appeal or invitation to virtue and leave evil (amar ma'ruf nahyi munkar). In other words, da'wah is al-amr bi al-ma'rūfwa alnahy an almunkar. This means that the existence and effort of da'wah can only be seen in the process of "telling the good and preventing the evil". Because preaching - existentially - can only be seen in the process of "commanding to the good and preventing the negation", so the da'wah must be carried out with real action (bi lisān al-hạal). Great commitment to this effort is concrete action from an actual da'wah activity[8].

The definition shows that the essence of true da'wah is the giving of motivation to everyone to do good deeds and avoid evil so that happiness is reached for the world and the hereafter. This is done by a caller (motivator), who is commonly referred to as a consciously and sincere preacher.

Performing da'wah activities is basically giving motivation to others. For this reason, it is necessary to pay attention to the needs of the target group. Moreover, the missionary estuary is none other than the attainment of world welfare and the hereafter. In this context, the meaning of da'wah stated by SahalMahfudh in the context of community empowerment[9]. Da'wah is every activity and activities of a person (a group) of Muslims, as a manifestation of their faith and realization of Islam, both verbally, with attitude, in the form of deeds and writings, to himself, his family, others and the community at large, so that they are obedient and obedient to God and subject to faithfully follow the sunnah of the Prophet, for the benefit of life in the world and in the hereafter .

Nowadays, some preachers understand da'wah merely as a verbal expression (da'wah bi allisan), through the mediation of television media. At the same time ignoring the other most important aspects of da'wah, namely by the act or da'wah bi al-hal. Delivering religious messages and messages of wisdom is not just rhetoric which is only a spectacle. But most importantly, they need to put forward aspects of guidance or real examples of virtue, simplicity in the form of real action. So, the subject of da'wah really understands and applies 
the da'wah material. The preachers can actually provide solutions to problems faced by the community.

Mahfudh argues preachers must, of course, have to know exactly and explore the needs of the community and explore the potential that is useful to meet the needs of groups in the short and long term. It is important to note, if da'wah is oriented towards meeting the needs of the community, then a participatory approach is needed. With this approach, needs are explored by preachers with the community[10]. Problem-solving is planned to be carried out together with preachers and the community. Even activities were assessed together to improve further activities. Such an approach requires a monitoring system in reporting. Thus, preaching does not do in top-down, which sometimes reaches the bottom does not solve the problem. Topdown model planning often ignores the mapping of problems, potentials, and specific obstacles based on region or group.

Da'wah activities are not just giving "recitation" on the tribune with various seasonings in front of the wider community, who greeted him with a round of applause echoing in the middle of the field. But more than that demands the growth of awareness for the community to make positive changes in their religious experience and insight.

In today's information and technology era, the term 'millennial generation' is becoming a hot topic in this country. This term is often a marker of the present or modern age (the age of now), in contrast to past generations or old times. Social researchers often classify it as a generation born between the 1980s and 2000s or it can be said that the intended generation is young people who are currently 17-37 years old [11]. This generation is synonymous with technology, especially the internet and social media. According to a Pew Research Center study (2010), millennial generation cannot be separated from the use of technology, especially the internet, because that has become their basic needs and most of them have social media. This generation was born as a marker of the new millennium, namely Millenia 21.

Quantitatively, millennials are an extraordinary number of people. Data released by the United Nations shows that teenagers constitute the most age group by almost all countries. According to the State of the World report released in 2003, one-fifth of the world's population is between the ages of 10 and 19. Country specific data is also vital to understand recent demographic trends. For example, in Kosovo, one-half of the population is aged under 20; in Nothern Ireland, $40 \%$ of the population is under 24; $37 \%$ in South Africa is under 15 and $19.3 \%$ is aged 15-24). In Gaza and the West Bank, over 50\% of the population is under 15 . And in the Middle East generally, more than $40 \%$ of the population is under 15 . In Guatemala, $20.3 \%$ of the population is aged 15-24 and in Siera Leone, $19 \%$ is aged $15-25$, and the percentage is on the rise."[12][13].

The development of digital technology has significantly influenced the millennial generation. Hence, the millennials can be easily and smoothly search for information from any part of the world. The millennial generation is able to receive various information from many sources, from all of them, which is alarming, not all information disseminated is true and infrequently the information received by millennial contains the provocation of radicalism, terrorism, intolerance, and hatred.

The Alvara Research Center has discussed more specifically about millennials generation, namely the urban middle-class millennials in Indonesia with all its implications through the whitepaper titled "Indonesia 2020: The Urban Middle-Class Millennials". The article is the first writing sourced from the desk research on secondary data, so we think we need further studies sourced from primary data. Meanwhile, this second study is a form of AlvaraReseach Center's commitment as a research institute that is concerned to current issues [14]. 
As an illustration, the middle-class urban millennials generation is a generation that has distinctive characteristics. In the previous article, referring to the millennial generation character as $3 \mathrm{C}$, comes from Creative, Confidence and Connected. First, the urban middleclass millennials are the creative generation. They are accustomed to thinking out of the box, rich in ideas and notions. Second, the urban middle-class millennials are a generation of confidence, they are very confident and dare to express their opinions without hesitation. Third, the urban middle-class Millenials are the connected generation. They are the generation who are good at socializing, especially in the communities they followed. In addition, it also surfs on social media and the internet. The character of the Millenials is much influenced by the rapid development of technology, especially gadgets, and the internet [14].

RenaldKasali said that the millennial generation is nicknamed the strawberry generation because it was "easy to rot" like strawberries[15]. Millennial characters cannot stand social or work pressure. The millennial generation - in general - is born from parents who are far more prosperous than previous generations. RhenaldKasali described this generation as a spoiled, irritable, easily despaired population, then gave up before achieving what was desired. The character is formed due to over-protection as the growth of millennial parental prosperity.

Millennials are raised to resemble the preconditions required to produce strawberries, which is a more protected and well-preserved environment compared to other fruit plants. Therefore, RhenaldKasali stressed the importance of full explanation and guidance on millennials - to millennials it must be reminded that life is basically a challenge, to deal with it, it requires mentally trained human beings, not actually avoiding challenges, so it takes fighting spirit to face challenges, not just stare and mourn - must be challenged and used to facing failure. They are the young generation who must be able to become the majority population that is full of creative ideas and resilient so that they do not become a generation that is "soft" and easily discouraged. Therefore, it is very important to understand and strengthen the role of millennials through increasing their capacity and quality as knowledgeable, creative and integrity people - as an effort to prepare millennials to become profitable ones, as bonuses. demographic (demographic dividend). Moreover, world competitiveness is increasingly high the center of betting is on the quality of human resources. In the Indonesian context, the focus and priority of improving the quality of human resources lie in youth resources.

In the era of social media, the millennial young generation can easily access and receive information and share it without confirming (tabayyun) first. Religious information from social media, Facebook, YouTube, Mbah Google, can be accessed easily and does not require confirmation (tabayyun). The millennial youth is very easily influenced by a variety of information that comes from anywhere. Especially if there is a cleric or young preacher, who provide religious information, directly swallowed it straightforwardly without observing

The issue of radical young people is increasingly concerned, based on a survey report of LaKIP (Institute for Islamic Studies and Peace) provides a picture that reinforces the alleged radicalization among young people (youth) especially junior and senior high school students in the Greater Jakarta area (Jakarta, Bogor, Depok, Tangerang, and Bekasi) gives an indication of the radical actions they support and dare to do as part of jihad. They seem to have quite broad support from young people in junior and senior high school [16]. When high school and junior high school children were asked how they were introduced to radical organizations they recognized them as much as $25.7 \%$ for students and $66.4 \%$ for teachers. While when asked whether they agree with radical organizations the teachers answered agree as much as $23.6 \%$, while students answered agree as much as $12.1 \%$. When asked whether they know the figures who have been known to be radical, the teachers answer as many as $59.2 \%$ and students know 
them as much as $26.6 \%$. And when questioned agree with radical figures the teachers answered agree as much as $23.8 \%$ while students who agreed reached $13.4 \%$.

A study conducted by the Center for Religious and Cross-Cultural Studies at Gadjah Mada University and the Yogyakarta Institute of Islamic and Social Studies (LKiS) in the Politics of School Public Spaces (2011), reported that in Yogyakarta there were a number of high schools (SMA) that had a strong tendency (radical) in understanding the religion that has been adhered to. The radicalization that they professed occurred because of the roles of the mentors namely the high school alumni in providing high school students with an understanding of Islam.

They are young people (average age 18-19 years old) referring to Nancy Smith Hefner (2005 and 2007), they carry out Islamic activities in schools by dominating public spaces such as being the organizer of the OSIS (Intra School Student Organization) an organization officially belongs to senior high schools and dominates Islamic activities in the Islamic Spiritual Unit (Rohis) organization, which since 1990 has spread everywhere, almost every public school in Yogyakarta, including leading schools and even international standard schools. They negotiated their Islamic interests by opposing the structures carried out through agencies maintained through the school's alumni network.

The results of research conducted by the Center for Religious and Cross-Cultural Studies at Gadjah Mada University and the Yogyakarta Institute of Islamic and Social Studies (LKiS) in the Politics of School Public Spaces (2011), indicated that in Yogyakarta there are several High Schools (SMA) that have a hard tendency (radical) in understanding the religion that has been adhered to. The survey showed $84.4 \%$ of students agreed to the enactment of Islamic law, while $25.8 \%$ considered Pancasila to be no longer relevant as the state foundation, the survey was conducted in 59 private schools and 41 state schools.

The results of several surveys or research above show that the young generation today is very vulnerable to radical understandings due to information being swallowed straightforwardly without the need for tabayyun or confirmation. This is worsened by the fact that millennial youth no longer feel the need to explore religious teachings, like in Islamic boarding schools. Likewise, the influence of social media is quite high in shaping the mindset and character of the current millennial generation. Media like, google, Facebook, Instagram, youtube become a reference for millennials in finding information about religion. This condition further aggravates the condition of the millennial generation who are trapped in a narrow religious understanding.

The condition of this millennial youth is a 'soft meal' for celebrities' preachers as a place to channel religious ideas. These preachers move through social media networks and other media to promote their ideas to answer the 'instant' needs of the millennial youth. The celebrity preachers became famous, defeating the clerics and professors in the field of religion, such as Quraish Shihab, Mustafa Bisri, Gus Dur, Nazaruddin Umar, and so on. Celebrity preachers fully understand the religious 'market' interests of the younger generation. They do not need to provide religious explanations that are too academic, meticulous and deep. The most important is, it can be accepted by the younger generation market. The appearance of the celebrity preachers was alleged by one of the young scholars of NU as " black market preacher".

The phenomenon of celebrity preacher is a form of 'da'wah modernization'. This is indicated by the widespread use of modernity projects for the benefit of da'wah for the community, especially those who "feel" modern in urban areas. In the past, da'wah was mostly carried out in mosques, prayer rooms and majelistaklim, now experiencing a shift. Information and technology media provide a very open space for these preachers to convey religious information. The da'wah objects don't need to be face to face with these 'idols'. The young 
generation simply needs to open cellphones or gadgets, laptops to access religious information conveyed by the preachers, through the e-da'wah network. Though this symptom ignores the psychological aspects of da'wah. A face-to-face meeting between the subject and the object of preaching is considered very important in the context of the success of the preaching itself. Even from that meeting, the object of preaching is not just watching, but also can be used as a guide of life. Or in the context of religion, the fulfillment of the essence of da'wah is not just verbal, but also with concrete action.

Virtual da'wah or e-da'wah that is mostly done by celebrity preachers is a form of using internet media for the purpose of da'wah and can be considered effective in reaching all levels of Indonesian society, especially internet users. Data shows that now is an era where the internet, including social media, has become a necessity for the community, especially the millennial generation. This can be seen from the following two research results. The results of the APJII survey (Association of Indonesian Internet Network Providers) show that in Indonesia in 2016 there were around 132.7 million internet users $( \pm 51.5 \%$ of the total population) (Rappler.com, 2016). Another survey conducted by the Global Web Index (2010) (quoted from Morissan, 2016) shows that internet users in Indonesia, among other Asian countries, are the most using social media (79.72\%), compared to Japan (30.1\%), Australia $(48.8 \%)$ and Singapore $(63 \%)$.

Of course, the use of the internet and social media in da'wah activities is a positive thing if it can influence open religious views and attitudes, especially among millennials. But on the other hand, like the two sides of the coin, this phenomenon can become boomerang if the religious information conveyed precisely makes the younger generation of millennials easily trapped into religious practices that deviate from common habits, such as radicalism and exclusivism. In fact, often the lifestyle of 'classy' in the style of celebrities is actually more imitated than the religious information conveyed. The phenomenon of celebrity preacher is indeed worrying for millennials when their emergence does not provide a positive benefit for the formation of character and religious understanding of open millennial aggression. Especially if what is offered is just a lifestyle, wardrobe, and so on. Even though most millennials are now starting to pay attention to religious activities, if there is no control and guidance from religious institutions, the media, and the government, it will further complicate the religious and religious conditions of Indonesian society.

\section{Conclusion}

The emergence of young preachers who tend to be celebrities and celebrities who 'suddenly' become a clericman and clericwoman as if answering the needs of the era, especially the younger generation who want to get religious information 'instantly'. Most of these celebrity preachers and celebrities have no profound religious understanding and capability. However, their existence is recognized as being able to answer and meet the needs of the millennial youth. This is supported by the use of information media to promote religious information. Another thing that should be noted, that the celebrity preachers have influenced the millennial youth in the religious discourse and practice of the homeland. Millennials are increasingly 'concerned' about religion. Religion, through appearance and lifestyle, has become the identity of young people, especially in urban areas. This condition needs to be appreciated without ignoring control and all parties. 


\section{References}

[1] A. C. Ulum and M. Haramain, "EKSISTENSI DAKWAH DALAM MERESPON PLURALISME," KOMUNIDA MEDIA Komun. DAN DAKWAH, vol. 7, no. 2, pp. 124-138, 2017.

[2] M. Dawud, "TAYANGAN DAKWAH DAN LAHIRNYA DA'I SELEBRITI," Al'Adalah, vol. 18, no. 2, 2016.

[3] A. Suroso, A. N. Rais, and A. A. Safei, "Juru dakwah sebagai selebritas," 2018.

[4] M. Haramain, "Pemikiran dan Gerakan Dakwah Tuan Guru M. Zainuddin Abdul Madjid di Lombok NTB.” Universitas Islam Negeri Alauddin Makassar, Makassar, 2012.

[5] N. Ahmad, "PROBLEMATIKA DAKWAHTAINMENT DI MEDIA DAKWAH."

[6] N. Ahmad, "Keterbukaan dakwahtainment sebagai media dakwah," J. At-Tabsyir, vol. Vol.2, no. No.1, pp. 17-34, 2014.

[7] M. Fakhruroji, "Komodifikasi Agama Sebagai Masalah Dakwah," Ilmu Dakwah Acad. J. Homilet. Stud., vol. 5, no. 16, pp. 1-18, 2010.

[8] A. A. Dani, "DAKWAH ISLAMIYAH: MENIMBANG KEMBALI KONSEP DAKWAH ISLAM MOHAMMAD NATSIR,” Dirosat J. Islam. Stud., vol. 1, no. 1, pp. 101-128, 2016.

[9] K. H. Sahal Mahfudh, "Nuansa Fiqh Sosial,” Yogyakarta LkiS, 1994.

[10] J. Ma'mur, "Implikasi Fiqh Sosial Kyai Sahal Mahfudh Terhadap Pembaharuan Fiqh Pesantren Di Kajen Pati," YUDISIA J. Pemikir. Huk. dan Huk. Islam, vol. 5, no. 1, 2016.

[11] N. Sabani, "GENERASI MILLENIAL DAN ABSURDITAS DEBAT KUSIR VIRTUAL," Informasi, vol. 48, no. 1, pp. 95-108, 2018.

[12] E. Najmuddin, "Respon Gerakan Islam Cinta Terhadap Ideologi Keagamaan di Kalangan Generasi Milenial.” Jakarta: Fakultas Ushuluddin Dan Filsafat UIN Syarif Hidayatullah, 2018.

[13] S. McEvoy-Levy, Youth as social and political agents: Issues in post-settlement peace building. Joan B. Kroc Institute for International Peace Studies, University of Notre Dame, 2001.

[14] H. Ali, L. Purwandi, H. Nugroho, A. Ekoputri, and T. Halim, "The Urban MiddleClass Millenials Indonesia: Financial And Online Behavior," Lap. Has. Penelitian. Jakarta Alvara Res. Center. Diakses dari website http/lalvara-strategic. com/wpcontent/uploads/whitepaper/The-Urban-Middle-Class-Millenials. pdf, vol. 10, 2017.

[15] D. Amalia and E. T. Gumilar, "Potret Remaja Kreatif Generasi?(Phi) Pengubah Indonesia," Konvensi Nas. Bimbing. dan Konseling XXI, pp. 189-197, 2019.

[16] Z. Qodir, "Perspektif Sosiologis tentang Radikalisasi Agama Kaum Muda," MAARIF, vol. 8, no. 1, pp. 45-66, 2013. 